\title{
Cell phone radiation effects on cytogenetic abnormalities of oral mucosal cells
}

\section{Natália Batista DAROIT(a) Fernanda VISIOLI(a) Alessandra Selinger MAGNUSSON(a) Geila Radunz VIEIRA(b) Pantelis Varvaki RADOS(a)}

(a) Universidade Federal do Rio Grande do Sul - UFRGS, School of Dentistry, Department of Oral Pathology, Porto Alegre, RS, Brazil.

(b) Prefeitura Municipal de Porto Alegre PMPA, Coordenação de Vigilância em Saúde, Porto Alegre, RS, Brazil.

Declaration of Interests: The authors certify that they have no commercial or associative interest that represents a conflict of interest in connection with the manuscript.

Corresponding Author:

Pantelis Varvaki Rados

E-mail:pantelis@ufrgs.br

DOI: 10.1590/1807-3107BOR-2015.vol29.0114

Submitted: Apr 17, 2015

Accepted for publication: Jul 28, 2015

Last revision: Aug 27, 2015
Abstract: The aim of this study was to evaluate the effects of exposure to cell phone electromagnetic radiation on the frequency of micronuclei, broken eggs cells, binucleated cells, and karyorrhexis in epithelial cells of the oral mucosa. The sample was composed of 60 cell phone users, who were non-smokers and non-drinkers, and had no clinically visible oral lesions. Cells were obtained from anatomical sites with the highest incidence of oral cancer: lower lip, border of the tongue, and floor of the mouth. The Feulgen reaction was used for quantification of nuclear anomalies in 1,000 cells/slide. A slightly increase in the number of micronucleated cells in the lower lip and in binucleated cells on the floor of the mouth was observed in individuals who used their phones $>60$ minutes/week. The analysis also revealed an increased number of broken eggs in the tongue of individuals owning a cell phone for over eight years. Results suggest that exposure to electromagnetic waves emitted by cell phones can increase nuclear abnormalities in individuals who use a cell phone for more than 60 minutes per week and for over eight years. Based on the present findings, we suggest that exposure to electromagnetic radiation emitted by cell phones may interfere with the development of metanuclear anomalies. Therefore, it is demonstrated that, despite a significant increase in these anomalies, the radiation emitted by cell phones among frequent users is within acceptable physiological limits.

Keywords: Mouth Mucosa; Micronucleus Tests; Cell Phones; Pathology.

\section{Introduction}

Over the past decade, the use of cell phones has increased significantly. Total cell phone subscriptions amounted to more than 6 billion in 2013, corresponding to a global penetration rate of $93.1 \%$ per 100 inhabitants. ${ }^{1}$ The rapid worldwide increase in cell phone users has raised health concerns about potential risks associated with exposure to electromagnetic fields produced by this technology. Given the large number of cell phone users, a negative effect may have huge public health implications. ${ }^{2}$

Ever since many aspects of human health that might be affected by cell phone exposure have been investigated, ranging from mild local warmth to possible tumor induction. ${ }^{3}$ The effects of electromagnetic radiation on biological systems are under evaluation by studies with contradictory results so far. ${ }^{4}$ Although a cause-effect relationship has not been established conclusively, there is a possibility that the incidence of 
cancer and other genetic or non-genetic pathological conditions may be associated with such exposure. ${ }^{5,6,7}$

Laboratory studies in different countries have shown that low-level electromagnetic radiation, such as that from cell phones, may lead to DNA strand breaks or structural damage. ${ }^{8}$ Methods for biomonitoring genetic damage include the use of intermediate biomarkers, micronuclei, and other nuclear anomalies that can signal lifestyle factors and/or environmental or occupational exposure to genotoxic agents. ${ }^{9} \mathrm{~A}$ higher frequency of oral mucosa micronuclei has been reported in response to carcinogen exposure, as a result of radiation, in the presence of potentially malignant lesions and in oral cancer. ${ }^{10,11,12,13}$

Other genotoxic abnormalities include: broken eggs - the mechanisms leading to their formation have not been fully elucidated, but they appear to be related to nuclear elimination of amplified DNA or DNA repair; karyorrhexis - a cellular process that involves nuclear fragmentation of probably late apoptotic cells, increased amounts of karyorrhectic cells may reflect a response to cytotoxic effects; and binucleated cells - their presence appears to indicate a failure of cytokinesis resulting from the last nuclear division in the basal layer. ${ }^{14}$

The oral cavity is within the area exposed to radiation emitted by cell phones. The existing reports in the literature investigating the influence of cell phone radiation on nuclear anomalies in the oral mucosa are contradictory: three of them report a positive correlation between cell phone use and genetic damage, ${ }^{15,16,17}$ and another two indicate the absence of such correlation. ${ }^{18,19}$ For this reason, more information on this matter is valuable. Therefore, the aim of this study is to evaluate the effects of exposure to cell phone electromagnetic radiation on the frequency of micronuclei, broken eggs, binucleated cells, and karyorrhexis in epithelial cells of the lip, on the border of the tongue, and on the floor of the mouth.

\section{Methodology}

The subjects were enrolled at the School of Dentistry, Universidade Federal do Rio Grande do Sul - UFRGS, Porto Alegre, Brazil. The inclusion criteria were: owning a cell phone whose Specific Absorption Rate (SAR) was two watts per kilogram of body weight, limit adopted by Brazil according to the Guidelines for Human Exposure to Radiofrequency Electromagnetic Fields for International Commission on Non-Ionizing Radiation Protection (ICNIRP); ${ }^{20}$ being a nonsmoker; not having clinically visible oral lesions (except for periodontal diseases); and reporting good general health. In addition, alcohol intake should be no more than two weekly doses $(340 \mathrm{~mL}$ of beer, $113 \mathrm{~mL}$ of wine, or $28 \mathrm{~mL}$ of distilled beverage). ${ }^{21}$

Sample calculation was performed according to Yadav and Sharma, ${ }^{15}$ using the mean (10.72) and standard deviation (8.194) found by the authors for the "Total micronucleus" variable. Considering a study with an $80 \%$ power and $\alpha=0.05$, the minimum sample size should be 44 individuals.

The present study was conducted in accordance with the ethical guidelines set forth in the Declaration of Helsinki. The study protocol was approved by the local Ethics Committee (protocol number 17764), and all patients signed an informed consent form prior to their inclusion. After providing the written informed consent, all participants answered a questionnaire to establish a profile of cell phone use. For the statistical analysis, the participants' weekly cell phone use was classified into 60 minutes or less $(n=32)$ and into 60 minutes or more $(n=28)$, whereas years of cell phone use was classified into eight years or less $(n=32)$ and into eight years or more $(n=28)$. A clinical examination of the oral cavity of these patients was conducted prior to the cytopathological sampling. Subjects with oral lesions were referred to the Division of Oral Pathology.

Cells were obtained by scraping areas of the oral mucosa at three anatomical sites (lower lip, border of the tongue, and floor of the mouth) using a sterile cytobrush. An attempt was made to collect samples on the preferential side used during phone calls; however, many individuals reported changing sides during the phone calls. Specimens were uniformly spread on histological slides, which were labeled with the number assigned to each participant as per anatomical site. The slides were then stored in $99 \%$ ethanol for subsequent Feulgen staining (Feulgen reaction kit, 1.07907, Merck KGaA, Darmstadt, Germany), which reacts specifically with DNA, reducing the risk of false positive staining. 
Quantification was performed by a single blinded and calibrated observer. The calibration was performed with an experienced researcher to determine the criteria for each type of metanuclear change. Intra-rater reliability was evaluated using the intraclass correlation coefficient, ICC $>0.75$. A total of 1,000 loosely spaced, distended cells were analyzed per slide at 1000x magnification, under oil immersion. Cells displaying karyolysis and pyknosis were discarded. The nuclear changes were quantified as follows: micronuclei (round or oval structures with well-defined borders, having $1 / 3$ to $1 / 6$ the diameter of the main nucleus, staining intensity and texture similar to that of the main nucleus, found in the same cytoplasm of the main nucleus); broken eggs (the nucleus presents a constriction that leaves it attached to a rounded structure ranging from $1 / 4$ to $1 / 2$ its diameter; broken eggs have the same morphology and staining as the nucleus and are usually close to it); karyorrhexis (nucleus with dense chromatin aggregate indicating nuclear fragmentation that may lead to disintegration); binucleated cells (those containing two main nuclei that are usually close to each other and have the same morphology) $)^{14}$ (Figure).

The nonparametric Mann-Whitney test was used to compare median values of nuclear changes at each anatomical site with past cell phone use (in years) and weekly cell phone use (in minutes). The Spearman correlation coefficient was used to analyze data on past and weekly cell phone use and on the count of nuclear changes. Statistical analysis was performed using the Statistical Package for the Social Sciences (SPSS) version 18.0 (SPSS Inc., Chicago, USA). The level of significance was set at $5 \%$.

\section{Results}

We evaluated 60 healthy individuals out of 180 samples. The study population consisted of $40 \%$ men and $60 \%$ women; mean age was 23.28 years, ranging from 19 to 33 years. The participants owned a cell phone for an average of 8.36 years (4-14 years) and spent an average of 128.6 minutes (10-1260 minutes) per week speaking on the phone.

The sample was divided into two groups: 60 minutes or less, and 60 minutes or more of cell phone use per week. Mean age was 23.28 years in the first group and 23.35 in the second one. A statistically significantly higher number of micronuclei were observed in the lower lip in the group that spoke for more than $60 \mathrm{~min} /$ week on the cell phone compared to individuals who spoke for less than $60 \mathrm{~min} /$ week. Also, an increased number of binucleated cells were observed on the floor of the mouth of these individuals (Table 1).

By analyzing the nuclear changes in the oral mucosa as a whole (all oral mucosal sites assessed were added together), the number of micronuclei was also higher among individuals who spoke for more than $60 \mathrm{~min} /$ week on the phone compared to those who spoke for less than $60 \mathrm{~min} /$ week (Table 2).

Another analysis was performed by splitting the sample into a group that owned a cell phone for eight years or less and into a group that owned it for more than eight years. Mean age was 23.218 years in the first group and 23.357 in the second one. Mean values of broken eggs were statistically higher on the border of the tongue of individuals owning a cell phone for over eight years (Table 3). No significant differences were observed when analyzing the nuclear changes in the oral mucosa as a whole (all oral mucosal sites assessed were added together) (Table 4).

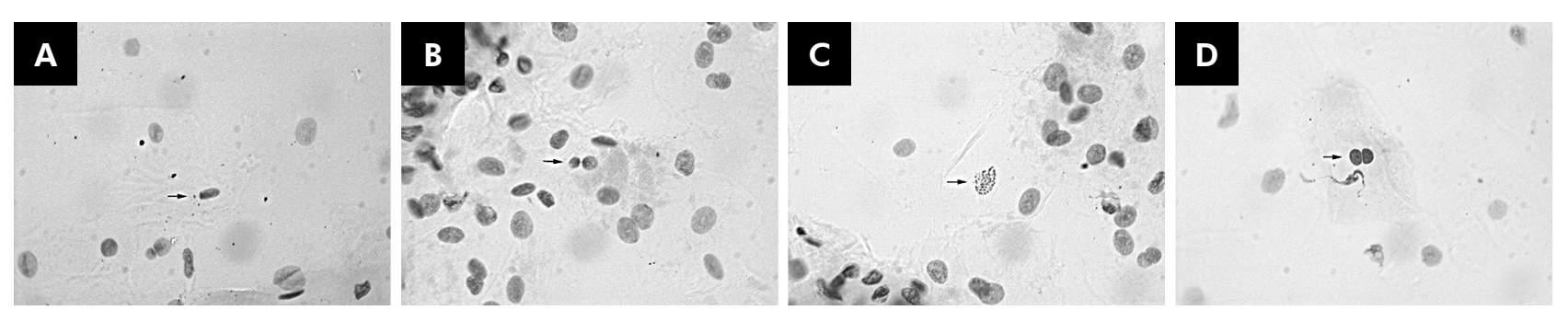

Figure. Cytogenetic abnormalities of oral mucosal cells exposed to cell phone radiation. A: micronuclei; B: broken egg; C: karyorrhexis; D: binucleated cell. Bar, $10 \mu \mathrm{m}$ (Feulgen stain, original magnification 1000x, under oil immersion). 
Table 1. Comparison of weekly cell phone use and mean values of nuclear changes at each anatomical site (1,000 cells).

\begin{tabular}{|c|c|c|c|c|c|}
\hline \multirow{3}{*}{ Site } & \multicolumn{4}{|c|}{ Weekly cell phone use } & \multirow{3}{*}{$p^{*}$} \\
\hline & \multicolumn{2}{|c|}{$\leq 60$ minutes $(n=32)$} & \multicolumn{2}{|c|}{$>60$ minutes $(n=28)$} & \\
\hline & Mean & SD & Mean & SD & \\
\hline \multicolumn{6}{|l|}{ Micronuclei } \\
\hline Lower lip & 0.063 & $( \pm 0.25)$ & 0.321 & $( \pm 0.61)$ & 0.040 \\
\hline Border of the tongue & 0.063 & $( \pm 0.25)$ & 0.142 & $( \pm 0.36)$ & 0.305 \\
\hline Floor of the mouth & 0.032 & $( \pm 0.17)$ & 0.036 & $( \pm 0.19)$ & 0.924 \\
\hline \multicolumn{6}{|l|}{ Broken eggs } \\
\hline Lower lip & 3.468 & $( \pm 5.18)$ & 3.928 & $( \pm 4.72)$ & 0.452 \\
\hline Border of the tongue & 1.312 & $( \pm 1.61)$ & 1.392 & $( \pm 2.13)$ & 0.802 \\
\hline Floor of the mouth & 0.531 & $( \pm 0.95)$ & 1.071 & $( \pm 1.74)$ & 0.240 \\
\hline \multicolumn{6}{|l|}{ Binucleated cells } \\
\hline Lower lip & 2.437 & $( \pm 4.84)$ & 2.892 & $( \pm 5.08)$ & 0.789 \\
\hline Border of the tongue & 0.5 & $( \pm 0.915)$ & 0.785 & $( \pm 1.34)$ & 0.380 \\
\hline Floor of the mouth & 0.312 & $( \pm 0.64)$ & 1.214 & $( \pm 2.17)$ & 0.032 \\
\hline \multicolumn{6}{|l|}{ Karyorrhexis } \\
\hline Lower lip & 12.062 & $( \pm 13.72)$ & 11.464 & $( \pm 12.65)$ & 0.835 \\
\hline Border of the tongue & 18.468 & $( \pm 22.43)$ & 12.928 & $( \pm 14.13)$ & 0.523 \\
\hline Floor of the mouth & 5.156 & $( \pm 6.30)$ & 4.964 & $( \pm 8.54)$ & 0.615 \\
\hline
\end{tabular}

* Nonparametric Mann-Whitney test.

Table 2. Comparison of weekly cell phone use and mean values of nuclear changes within the whole oral mucosa (3,000 cells).

\begin{tabular}{|c|c|c|c|c|c|}
\hline & \multicolumn{4}{|c|}{ Weekly cell phone use } & \multirow{3}{*}{$\mathrm{p}^{*}$} \\
\hline & \multicolumn{2}{|c|}{$\leq 60$ minutes $(n=32)$} & \multicolumn{2}{|c|}{$>60$ minutes $(n=28)$} & \\
\hline & Mean & SD & Mean & SD & \\
\hline Micronuclei & 0.052 & $( \pm 0.22)$ & 0.167 & $( \pm 0.43)$ & 0.048 \\
\hline Broken eggs & 1.770 & $( \pm 3.38)$ & 2.131 & $( \pm 3.37)$ & 0.332 \\
\hline Binucleated cells & 1.083 & $( \pm 2.99)$ & 1.631 & $( \pm 3.36)$ & 0.191 \\
\hline Karyorrhexis & 11.896 & $( \pm 16.34)$ & 9.786 & $( \pm 12.37)$ & 0.419 \\
\hline
\end{tabular}

* Nonparametric Mann-Whitney test.

Table 3. Comparison of years of cell phone use and mean values of nuclear changes at each anatomical site $(1,000$ cells).

\begin{tabular}{|c|c|c|c|c|c|}
\hline \multirow{3}{*}{ Site } & \multicolumn{4}{|c|}{ Years of cell phone use } & \multirow{3}{*}{$p^{*}$} \\
\hline & \multicolumn{2}{|c|}{$\leq 8$ years $(n=32)$} & \multicolumn{2}{|c|}{$>8$ years $(n=28)$} & \\
\hline & Mean & SD & Mean & SD & \\
\hline \multicolumn{6}{|l|}{ Micronuclei } \\
\hline Lower lip & 0.218 & $( \pm 0.49)$ & 0.142 & $( \pm 0.45)$ & 0.410 \\
\hline Border of the tongue & 0.125 & $( \pm 0.33)$ & 0.071 & $( \pm 0.26)$ & 0.494 \\
\hline Floor of the mouth & 0.063 & $( \pm 0.25)$ & 0.000 & $( \pm 0.00)$ & 0.182 \\
\hline \multicolumn{6}{|l|}{ Broken eggs } \\
\hline Lower lip & 4.437 & $( \pm 5.79)$ & 2.821 & $( \pm 3.65)$ & 0.253 \\
\hline Border of the tongue & 0.875 & $( \pm 1.36)$ & 1.892 & $( \pm 2.19)$ & 0.033 \\
\hline Floor of the mouth & 0.937 & $( \pm 1.64)$ & 0.607 & $( \pm 1.03)$ & 0.521 \\
\hline \multicolumn{6}{|l|}{ Binucleated cells } \\
\hline Lower lip & 3.156 & $( \pm 5.83)$ & 2.071 & $( \pm 3.63)$ & 0.567 \\
\hline Border of the tongue & 0.593 & $( \pm 0.91)$ & 0.678 & $( \pm 1.36)$ & 0.671 \\
\hline Floor of the mouth & 0.875 & $( \pm 1.98)$ & 0.571 & $( \pm 1.03)$ & 0.790 \\
\hline \multicolumn{6}{|l|}{ Karyorrhexis } \\
\hline Lower lip & 11.25 & $( \pm 12.97)$ & 12.39 & $( \pm 13.50)$ & 0.783 \\
\hline Border of the tongue & 15.71 & $( \pm 18.00)$ & 16.07 & $( \pm 20.44)$ & 0.750 \\
\hline Floor of the mouth & 5.968 & $( \pm 6.54)$ & 4.035 & $( \pm 8.21)$ & 0.329 \\
\hline
\end{tabular}

\footnotetext{
* Nonparametric Mann-Whitney test.
} 
Table 4. Comparison of years of cell phone use and mean values of nuclear changes within the whole oral mucosa (3,000 cells).

\begin{tabular}{|c|c|c|c|c|c|}
\hline & \multicolumn{4}{|c|}{ Years of cell phone use } & \multirow{3}{*}{$p^{*}$} \\
\hline & \multicolumn{2}{|c|}{$\leq 8$ years $(n=32)$} & \multicolumn{2}{|c|}{$>8$ years $(n=28)$} & \\
\hline & Mean & SD & Mean & SD & \\
\hline Micronuclei & 0.406 & $( \pm 0.614)$ & 0.214 & $( \pm 0.568)$ & 0.106 \\
\hline Broken eggs & 6.25 & $( \pm 7.15)$ & 5.32 & $( \pm 4.86)$ & 0.627 \\
\hline Binucleated cells & 4.62 & $( \pm 7.31)$ & 3.32 & $( \pm 4.07)$ & 0.786 \\
\hline Karyorrhexis & 32.94 & $( \pm 28.09)$ & 32.50 & $( \pm 29.33)$ & 0.755 \\
\hline
\end{tabular}

* Nonparametric Mann-Whitney test.

\section{Discussion}

The rapid growth in the number of cell phone users has raised questions about possible biological effects of the radiation emitted by these appliances. The oral mucosa is located within an area exposed to radiation emitted by cell phones; therefore, it is important to investigate its effects on oral mucosal cells. The findings of this study suggest that long-term exposure to cell phone radiation can slightly increase the frequency of cytogenetic abnormalities, such as micronuclei, broken eggs, and exfoliated oral mucosal binucleated cells.

A group of researchers studying the micronucleus assay denominated The Human Micronucleus Project on Exfoliated Buccal Cells $\left(\mathrm{HUMN}_{\mathrm{xL}}\right)$ made a worldwide survey on studies reporting micronucleus frequency in 30 different laboratories and estimated that spontaneous MN frequency of subjects not exposed to genotoxic chemical agents or radiation was $0.74 \%$ o (95\% CI 0:52 to $1: 05) .{ }^{22}$ Although an increase in nuclear abnormalities was observed, the mean of $\mathrm{MN}$ is still lower than that found in patients with potentially malignant carcinomas. Pelliciolli et al. ${ }^{12}$ used a similar methodology and observed that the MN median was 1 per 1,000 cells for patients with leukoplakia and 2 per 1,000 cells for patients with squamous cell carcinomas. Therefore, that demonstrates that, despite a significant increase in micronuclei in individuals who use their cell phones for a longer time, the radiation emitted by the appliances is within acceptable physiological limits.

To date, the literature on this topic has been contradictory, and a literature review encountered five studies about the effects of radiation emitted by cell phones on the oral mucosa, which yielded contrasting results. Yadav and Sharma ${ }^{15}$ found an increased frequency of micronucleated exfoliated cells in 85 cell phone users compared to 24 non-users (controls). Gandhi and Prabhjot ${ }^{16}$ also found a positive correlation between the number of micronuclei and increasing exposure to cell phone radiation, comparing 25 users with 25 controls. Souza et al. ${ }^{17}$ did not find any correlation between micronuclei and radiofrequency exposure; however, this study reports an increase of broken eggs in the group with greater exposure. Meanwhile, the studies conducted by Hintzsche and Stopper ${ }^{18}$ and Ros-Lior et al. ${ }^{19}$ did not find such correlation. The oral mucosa shows different degrees of keratinization according to the anatomical site; for example, the lip demonstrates greater keratinization compared to the tongue and to the floor of the mouth, ${ }^{23}$ but even with these different patterns, our results showed statistically significant differences at all sites analyzed; furthermore, we conducted this investigation on anatomical sites where oral cancer is more prevalent: lower lip, border of the tongue, and floor of the mouth. ${ }^{24}$ The differences between our results and those of other studies may be in part explained by the different sites analyzed, as the sites we assessed are likely more susceptible to cytogenetic alterations. ${ }^{25}$

By comparing the changes by anatomical site, we found that the lower lip had a higher mean of broken eggs and binucleated cells. This data indicates that such a site has the largest cellular repair compared to the other ones. Another possible explanation is that it is exposed to external agents such as solar radiation and, in addition, the studied local site is closest to the physically electromagnetic radiation source. The border of the tongue had 
more karyorrhectic cells than did the other sites. Such cytogenetic damage is explained when the cell cannot reverse the damage, being thus eliminated from the body, suggesting that the oral mucosa may present different ways to adapt to the same stimulus. ${ }^{14}$ Regarding all the nuclear modifications studied, the floor of the mouth had the lowest averages, which suggests that it would be the most protected site from cell phone radiation, with the buccal mucosa and tongue acting as physical and biological barriers.

It is also important to highlight that different staining techniques were used. Yadav and Sharma ${ }^{15}$ used orcein, which is not a DNA-specific stain and thus might not only stain DNA-containing micronuclei, but also other artifacts that are not associated with genomic instability, which can explain the very high number of micronuclei. The other studies used DNA-specific stains, which provide added specificity to the results. Hintzsche and Stopper ${ }^{18}$ used chromomycin A3; Ros-Lior et al. ${ }^{19}$ used DAPI; Gandhi and Prabhjot ${ }^{16}$ and Souza et al..$^{17}$ used acid-Schiff's reagent; and in this study, the Feulgen reaction was performed.

Nowadays, most of the Brazilian population aged 25-34 years old (83\%) has a cell phone, according to data from the Instituto Brasileiro de Geografia e Estatística - IBGE. In addition, with respect to occupation, $88 \%$ of agricultural workers had no cell phone for personal use. ${ }^{26}$ Therefore, we did not include a control group, as the results would be biased by factors such as age, different lifestyles, and eating habits.

Another controversial topic is the number of cells quantified for the assessment of micronuclei. Since micronuclei are a rare event, some authors suggest that the quantification of 1,000 cells per sample is not enough. ${ }^{14,22,27}$ In our study, three samples were collected from each individual; therefore, it was possible to compare the mean values of nuclear changes at all sites at the same time in order to increase the number of cells evaluated (3,000 cells). The simultaneous analysis of all sites also resulted in an increased number of micronuclei in individuals who used the phone $>60 \mathrm{~min} /$ week, thus confirming previous results.
Khurana et al. ${ }^{8}$ showed ipsilateral predisposition to brain cancers in cell phone users, but not on the contralateral side; therefore, some studies have distinct analyses for the left and right sides of the brain. In this study, such analysis was not performed, because during the interview, individuals showed difficult in pointing out the side they used more frequently, and many individuals also reported changing sides during calls.

In this study, in addition to micronuclei, other nuclear anomalies were analyzed, because cells presenting broken eggs, karyorrhexis or two nuclei are also biomarkers of genomic damage in the context of cytotoxicity and cytostatic effects. ${ }^{27} \mathrm{An}$ increased number of broken eggs were observed in the tongue of individuals who owned a cell phone for over eight years. Broken eggs are an early nuclear change, which may be associated with DNA repair or elimination of amplified DNA. ${ }^{10,27}$ As the subjects of this study did not smoke and did not consume alcohol chronically, they had no clinically visible oral lesions and reported no general health problems. We can thus suggest the occurrence of time-dependent genetic instability (in years of use) due to low-level exposure to electromagnetic radiation. In addition, an increased number of binucleated cells were observed on the floor of the mouth in those who used cell phones $>60 \mathrm{~min} /$ week. It is known that binucleated cells indicate a failure of cytokinesis, probably a defective cell-cycle checkpoint for aneuploidy. ${ }^{14}$

\section{Conclusion}

The presence of micronuclei and other nuclear anomalies, such as those assessed in this study, is classically associated with genetic defects that interfere with genome maintenance. ${ }^{14,22,26}$ Based on the present findings, we suggest that exposure to electromagnetic radiation emitted by cell phones may interfere with the development of metanuclear alterations in individuals who use a cell phone for more than 60 minutes per week and for over eight years. To further investigate the effects of this increased cytogenetic abnormalities caused by cell phone radiation exposure, it is necessary to assess the effects of electromagnetic radiation in the same 
individual from a cumulative perspective. Therefore, we strongly suggest that future studies on this subject should analyze sites considered to be of high risk for oral cancer aside from the oral mucosa.

\section{References}

1. International Telecommunication Union. Statistics of Mobile Cellular. Switzerland: ICT Data and Statistics. [cited 2014 Sep 9]. Available from: http://www.itu.int/ en/ITU-D/Statistics/Pages/stat/default.aspx?utm_ source $=$ twitterfeed\&utm_medium $=$ twitter

2. Khurana VG, Hardell L, Everaert J, Bortkiewicz A, Carlberg M, Ahonen M. Epidemiological evidence for a health risk from mobile phone base stations. Int J Occup Environ Health. 2010;16(3):263-7. doi:10.1179/oeh.2010.16.3.263

3. Swerdlow AJ, Feychting M, Green AC, Leeka Kheifets LK, Savitz DA. Mobile phones, brain tumors, and the interphone study: where are we now? Environ Health Perspect. 2011;119(11):1534-8. doi:10.1289/ehp.1103693

4. Ruediger H. Genotoxic effects of radiofrequency electromagnetic fields. Pathophysiology 2009;16(2-3):89-102. doi:10.1016/j.pathophys.2008.11.004

5. Schoemaker MJ, Swerdlow AJ, Ahlbom A, Auvinen A, Blaasaas KG, Cardis E et al. Mobile phone use and risk of acoustic neuroma: results of the Interphone case-control study in five North European countries. Br J Cancer. 2005;93(7):842-8. doi:10.1038/sj.bjc.6602764

6. Hardell L, Carlberg M, Hansson Mild K. Pooled analysis of two case-control studies on use of cellular and cordless telephones and the risk for malignant brain tumours diagnosed in 1997-2003. Int Arch Occup Environ Health. 2006;79(8):630-9. doi:10.1007/s00420-006-0088-5

7. Sadetzki S, Chetrit A, Jarus-Hakak A, Cardis E, Deutch Y, Duvdevani $S$ et al. Cellular phone use and risk of benign and malignant parotid gland tumors: a nationwide case-control study. Am J Epidemiol. 2008;167(4):457-67. doi:10.1093/aje/kwm325

8. Khurana VG, Teo C, Kundi M, Hardell L, Carlberg M. Cell phones and brain tumors: a review including the longterm epidemiologic data. Surg Neurol. 2009;72(3):205-14. doi:10.1016/j.surneu.2009.01.019

9. Fenech M. Cytokinesis-block micronucleus cytome assay. Nat Protoc. 2007;2(5):1084-104. doi:10.1038/nprot.2007.77

10. Bohrer PL, Sant'Ana Filho M, Paiva RL, Lauxen IS, Rados PV. Assessment of micronucleus frequency in normal oral mucosa of patients exposed to carcinogens. Acta Cytol. 2005;49(3):265-72. doi:10.1159/000326148

11. Silva AE, Rados PV, Lauxen IS, Gedoz L, Villarinho EA, Fontanella V. Nuclear changes in tongue epithelial cells following panoramic radiography. Mutat Res. 2007;632(1-2):121-5. doi:10.1016/j.mrgentox.2007.05.003

\section{Acknowledgments}

This work was supported by Coordenação de Aperfeiçoamento de Pessoal de Nível Superior CAPES, Brazil.

12. Pellicioli AC, Visioli F, Ferreira LA, Danilevicz CK, Carrard VC, Rados PV. Cytogenetic abnormalities in exfoliated oral mucosal cells and their association with oral cancer. Anal Quant Cytol Histol. 2011;33(5):271-6. doi:10.1155/2013/905252

13. Kamboj M, Mahajan S. Micronucleus: an upcoming marker of genotoxic damage. Clin Oral Invest. 2007;11(2):121-6. doi:10.1007/s00784-006-0075-y

14. Thomas P, Holland N, Bolognesi C, Kirsch-Volders M, Bonassi S, Zeiger E et al. Buccal micronucleus cytome assay. Nat Protoc. 2009;4(6):825-37. doi:10.1038/nprot.2009.53

15. Yadav AS, Sharma MK. Increased frequency of micronucleated exfoliated cells among humans exposed in vivo to mobile telephone radiations. Mutat Res. 2008;650(2):175-80. doi:10.1016/j.mrgentox.2007.11.005

16. Gandhi G, Prabhjot S. Cytogenetic damage in mobile phone users: preliminary data. Int J Hum Genet. 2005;5(4):259-65.

17. Souza LCM, Cerqueira EMM, Meireles JRC. Assessment of nuclear abnormalities in exfoliated cells from the oral epithelium of mobile phone users. Electromagn Biol Med. 2014;33(2):98-102. doi:10.3109/15368378.2013.783856

18. Hintzsche H, Stopper H. Micronucleus frequency in buccal mucosa cells of mobile phone users. Toxicol Lett. 2010;193(1):124-130. doi:10.1016/j.toxlet.2009.12.016

19. Ros-Llor I, Sanchez-Siles M, Camacho-Alonso F, Lopez-Jornet P. Effect of mobile phones on micronucleus frequency in human exfoliated oral mucosal cells. Oral Dis. 2012;18(8):786-92. doi:10.1111/j.1601-0825.2012.01946.x

20. Agência Nacional de Telecomunicações, Assessoria Parlamentar e de Comunicação Social. Celulares terão de atender ao limite de 2 Watts por KG para serem certificados. Brasília (DF): Agência Nacional de Telecomunicações; 2001 [cited 2014 Aug 26] Available from: http://www.anatel.gov.br/Portal/ verificaDocumentos/documento.asp?numeroPublicacao $=24730$ \&assuntoPublicacao=Celulares $\% 20$ ter $\square$ o\%20de\%20atender $\% 20$ ao\%20limite\%20de $\% 202 \% 20$ watts\%20por $\% 20 \mathrm{~kg} \% 20$ para $\% 20$ serem $\% 20$ certificados\&caminhoRel=null\&filtro $=1 \&$ docume ntoPath=biblioteca/releases/2001/release_06_04_2001(3).pdf

21. Tezal M, Grossi SG, Ho AW, Genco RJ. The effect of alcohol consumption on periodontal disease. J Periodontol. 2001;72(2):183-9. doi:10.1902/jop.2001.72.2.183

22. Bonassi S, Coskun E, Ceppi M, Lando C, Bolognesi C, Burgaz $S$ et al. The HUman MicroNucleus project on eXfoLiated buccal cells (HUMNXL): the role of life-style, host factors, occupational exposures, health status, and assay protocol. Mut Res. 2011;728(3):88-97. doi:10.1016/j.mrrev.2011.06.005 
- Cell phone radiation effects on cytogenetic abnormalities of oral mucosal cells

23. Adams D. Keratinization of the oral epithelium. Ann R Coll Surg Engl. 1976;58(5):351-8.

24. Gervásio OLAS, Dutra RA, Tartaglia SM, Vasconcellos WA, Barbosa AA, Aguiar MC. Oral squamous cell carcinoma: a retrospective study of 740 cases in a Brazilian population. Braz Dent J. 2001;12(1):57-61.

25. Angelieri F, Moleirinho TCG, Carlin V, Oshima CTF, Ribeiro DA. Biomonitoring of oral epithelial cells in smokers and non-smokers submitted to panoramic X-ray: comparison between buccal mucosa and lateral border of the tongue. Clin Oral Invest. 2010;14(6):669-74. doi:10.1007/s00784-009-0345-6
26. Instituto Brasileiro de Geografia e Estatística. Pesquisa Nacional por Amostra de Domicílios, 2011 - Posse de Celular. Rio de Janeiro: Instituto Brasileiro de Geografia e Estatística; 2011 [cited 2014 Aug 27]. Available from: http://ftp.ibge.gov.br/Acesso_a_ internet_e_posse_celular/2011/PNAD_Inter_2011.pdf

27. Holland N, Bolognesi C, Kirsch-Volders M, Bonassi S, Zeiger E, Knasmueller S, Fenech M. The micronucleus assay in human buccal cells as a tool for biomonitoring DNA damage: the HUMN project perspective on current status and knowledge gaps. Mutat Res. 2008;659:93-108. doi:10.1016/j.mrrev.2008.03.007 